\title{
STABILITY OF THE SUPPLY CHAIN BASED ON DISRUPTION CLASSIFICATION
}

\author{
Hui Hu, Lei Shi, Hai Ma, Bin Ran
}

Original scientific paper Disruptions can destroy the stability of a supply chain resulting in losses in business, thus, determining the influence of various disruptions on a supply chain is significant. However, current studies have mainly concentrated on the stability of a supply chain under normal conditions, exploring the effects of inventory level on the system state and omitting the influences of disruptions. With the lack of analysis on the characteristics of disruption when modelling switched system, disruptions were classified and the lead time of each disruption level was determined. Dual switch rules were proposed considering the stock dynamics and lead time delays. A switched system model of the supply chain with multiple delays was then constructed. System stability under different level disruptions was investigated using simulation method. Results show that the stability scope of inventory adjustment coefficients decreases as transport lead time and distance coefficients increase. Disruption classification has different effects on the supply chain. Under high level disruption, the inventory level of manufacture significantly changes, and the supply chain system loses its stability and encounters difficulty in recovering its stable state. However, under general disruption, the supply chain system recovers to stability gradually. The present exploration enriches the switched modelling method of the supply chain and helps its chain members prevent and respond to disruptions effectively.

Keywords: disruption; stability; supply chain; switched system

Stabilnost opskrbnog lanca na temelju klasifikacije poremećaja

Izvorni znanstveni članak

Poremećaji mogu uništiti stabilnost opskrbnog lanca što rezultira poslovnim gubitkom, pa je određivanje utjecaja raznih poremećaja na opskrbni lanac značajno. Međutim, postojeće su se analize uglavnom usredotočile na stabilnost opskrbnog lanca u normalnim uvjetima, a istraživale su učinke razine zaliha na stanje sustava i izostavljale utjecaj poremećaja. S nedostatkom analize o karakteristikama poremećaja prilikom modeliranja prebacivog sustava, poremećaji su klasificirani i određeno je vrijeme provedbe svake poremećene razine. Predložena su dvojna pravila prebacivanja s obzirom na dinamiku zaliha i zastoja u isporuci. Izrađen je model prebacivog sustava opskrbnog lanca s višestrukim zastojima. Stabilnost sustava pod različitim razinama poremećaja ispitana je pomoću simulacijske metode. Rezultati pokazuju da se opseg stabilnosti koeficijenata prilagodbe zaliha smanjuje s porastom koeficijenta vremena prijevoza i udaljenosti. Klasifikacija poremećaja ima različite učinke na opskrbni lanac. Pod poremećajem na visokoj razini, razina zaliha proizvodnje značajno se mijenja, a sustav opskrbnog lanca gubi svoju stabilnost i susreće se s poteškoćama u vraćanju na stabilno stanje. Međutim, pod općim poremećajem, sustav opskrbnog lanca postupno se vraća u stabilnost. Sadašnje istraživanje obogaćuje pomaknutu metodu modeliranja opskrbnog lanca i pomaže članovima lanca da učinkovito sprječavaju i reagiraju na poremećaje.

Ključne riječi: opskrbni lanca; poremećaj; prebacivani sustav; stabilnost

\section{Introduction}

Supply chain is a complex system with various types of uncertainties. Consequently, the rapid development of economic globalization and competition internationalization strengthens the dynamics and complexity of the supply chain environment, which threatens its stability. Recently, disruptions occur frequently. Disruptions can lead to cost increase, business interruption, enterprise bankruptcy, and even supply chain disintegration, which damages the stability of a supply chain [1]. Hence, supply chain members must understand the effect of disruptions on the performance of a supply chain and grasp the rules of evolution under disruptions to minimize the damage and loss of members. However, current studies on supply chain stability have mainly focused on stability judgment under normal conditions, such as internal production disturbance and change in the inventory level of enterprises. Moreover, studies on supply chain stability and evolution under disruptions remain lacking, and the different effects of disruption characteristics on a supply chain system are ignored. In recent years, switched system theory was introduced into supply chain area. In modelling switched system, current studies have extracted the single rule from stock dynamics, which ignored the characteristics of disruptions, as shown in References [2 $\div 5]$. Hence, considering the switched characteristics of a supply chain under disruptions, a switched system model with dual switch rules of stock dynamics and disruption characteristics is built. System stability under different levels of disruptions is investigated using simulation, thereby significantly improving the modelling technique and related research areas, as well as being practically significant for supply chain members to efficiently prevent and react to disruptions and reduce costs and losses.

\section{State of the art}

Current studies on the stability of supply chain have focused on stability under normal conditions. Supply chain stability has been studied in the literature $[6 \div 9]$. Stability judging methods include the Lyapunov stability principle, information entropy, network control, robust control, and simulation method $[10 \div 13]$. However, stability has rarely been analysed under disruptions, and studies on the stability of supply chain switched system under disruptions are still lacking, especially the system of dual switch rules.

Theory of switched system was recently introduced into supply chain research. Liu et al. [2] analysed the stability and dynamic characteristics of some two-stage supply chains with the switched model and linear matrix inequality (LMI) tool in Matlab. The distributor stock was divided into sufficient and insufficient or 0 , which was also the switch rule source. $\mathrm{Hu}$ [3] studied the stability of a three-stage supply chain with production capability and time delay constraints. Based on switched system 
modelling, supply chain stability was analysed with Matlab simulation. Li et al. [4] investigated the problem of $\mathrm{H} \infty$ control for a closed-loop supply chain (CLSC) system. Delayed input control strategy was adopted, and sufficient conditions were provided to guarantee the stability as well as the $\mathrm{H} \infty$ performance for the CLSC system. In the model, switch rule was based on the stock level of the manufacturing and recycling warehouses, which is still under the single switch rule problem. Garcia et al. [5] proposed a switched control system for a serial supply chain under a decentralized control strategy. Moreover, stock conditions were divided into infinite supply and high stock, infinite supply and low stock, and limited supply. The switch rule was the stock dynamics of each echelon. Simulation results indicated that the switching control was more effective than the proportional and integral control policy on inventory tracking. The current study extracted single switched rule from the inventory dynamics and concentrated on how the inventory level would affect the stability of supply chain. Switched system modelling failed to consider disruption characteristics and excluded dual rules.

On the characteristics of disruptions, Wilson [14] divided the disruptions into natural disaster, labour dispute, dependence on a single supplier, supplier bankruptcy, terrorism, war, and political instability. Oke et al. [15] investigated the types and management of risks faced within the supply chain of retailer and categorized disruptions into inherent or highly frequent risks and disruption or infrequent risks. Disruptions are caused by either natural (e.g., earthquake, floods, fire, and tsunamis) or man-made risks (e.g., terrorist attacks, accidents, and cyber-attacks) $[16,17]$. In addition to these disruptions, supply chains face interruptions caused by several sources with inherent uncertainties, such as demand fluctuations, supply capacity changes, lead time variability, and exchange rate volatility [18]. Combined with the characteristics of the evolution of supply chain disruptions, Sun and Ji [19] divided evolution into three stages, such as the prevention phase, control phase, and response stage. On the impact of disruptions, Qin [20] studied how changing market demands and production costs of manufacturer caused by disruptions affected supply chains. Ji [21] discussed the relationship between the operation parameters of supply chain and the diffusion of disruptions and created a loss assessment system of disruptions. These studies analysed the characteristics of supply chain considering the cause, frequency, evolving stage, and impact. Considerably, exploring the impact of various disruptions on the supply chain and revealing the interactive relationship between supply chain and disruptions are new directions that premise the grasp on the rules of supply chain evolution. In our study, disruptions have various effects on transportation, leading to various delays. Thus, disruptions are classified into different levels according to impact degrees. In this manner, we can find the quantitative relationship between disruptions of different levels and delays of lead time and build the switched model with dual rules.

The remainder of this study is organized as follows. Section 3 is dedicated to the modelling of supply chains under disruptions based on switched system theory. Section 4 demonstrates the simulation of supply chain stability under different levelled disruptions and provides sensitivity analysis. Finally, Section 5 presents conclusions and some ideas for further works.

\section{Methodology \\ 3.1 Classifications of disruptions}

In this study, disruptions refer to incidents that directly affect road transport conditions and cause delays, such as earthquakes, floods, and snowstorms.

\subsubsection{Disruption levels and their impact on transportation}

Disruptions are divided into four categories, namely, highly serious, serious, relatively serious, and general. Tab. 1 shows the impact of disruptions of different levels on transportation.

Table 1 Impact of disruptions of different levels on transportation

\begin{tabular}{|c|c|c|c|c|}
\hline \multirow[b]{2}{*}{$\begin{array}{l}\text { Indicator } \\
\text { Level }\end{array}$} & \multicolumn{4}{|c|}{ Disruption level } \\
\hline & $\begin{array}{l}\text { Level I } \\
\text { (highly } \\
\text { serious) }\end{array}$ & $\begin{array}{l}\text { Level II } \\
\text { (serious) }\end{array}$ & \begin{tabular}{|c|} 
Level III \\
(relatively \\
serious)
\end{tabular} & $\begin{array}{l}\text { Level IV } \\
\text { (general) }\end{array}$ \\
\hline $\begin{array}{c}\text { Disturbance } \\
\text { level }\end{array}$ & Interruption & $\begin{array}{c}\text { Serious } \\
\text { congestion }\end{array}$ & Congestion & Slow traffic \\
\hline $\begin{array}{l}\text { Damage } \\
\text { degree } \\
\text { of roads }\end{array}$ & $\begin{array}{c}\text { All roads } \\
\text { are damaged } \\
\text { badly }\end{array}$ & $\begin{array}{c}\text { Some roads } \\
\text { are damaged } \\
\text { seriously } \\
\text { and cars can } \\
\text { barely go } \\
\text { through } \\
\end{array}$ & $\begin{array}{l}\text { Some roads } \\
\text { are damaged } \\
\text { and cars } \\
\text { move } \\
\text { slowly }\end{array}$ & $\begin{array}{l}\text { Some roads } \\
\text { are damaged } \\
\text { slightly and } \\
\text { cars move at } \\
\text { low speed }\end{array}$ \\
\hline $\begin{array}{l}\text { Remaining } \\
\text { capacity of } \\
\text { roads }\end{array}$ & $<20 \%$ & {$[20 \%, 50 \%)$} & {$[50 \%, 80 \%)$} & $\geq 80 \%$ \\
\hline $\begin{array}{l}\text { Connectivit } \\
\text { y of road } \\
\text { network }\end{array}$ & $\begin{array}{c}\text { Poor } \\
\text { connectivity }\end{array}$ & $\begin{array}{c}\text { General } \\
\text { density and } \\
\text { connectivity }\end{array}$ & $\begin{array}{c}\text { Dense roads } \\
\text { and good } \\
\text { connectivity }\end{array}$ & $\begin{array}{c}\text { High } \\
\text { density of } \\
\text { roads and } \\
\text { excellent } \\
\text { connectivity }\end{array}$ \\
\hline $\begin{array}{l}\text { Average } \\
\text { speed of } \\
\text { road } \\
\text { network } \\
(\mathrm{km} / \mathrm{h})\end{array}$ & {$[0,19)$} & {$[19,22)$} & {$[22,28)$} & $\geq 28$ \\
\hline
\end{tabular}

\subsubsection{Disruption impact on transportation lead time}

As shown in Tab. 1, the impact of disruptions can be expressed quantitatively by the speed. The disruption is more serious, so the speed is lower [22]. The median of average speed is regarded as the speed of roads. In level IV, the speed is set as $50 \mathrm{~km} / \mathrm{h}$. Assuming the distance is $S^{*}(\mathrm{~km})$ and the lead time is $L(\mathrm{~s})$, Tab. 2 shows the impact of different disruption levels on lead time.

\begin{tabular}{|} 
Table 2 Impact of disruptions of different levels on the lead time \\
\begin{tabular}{|c|c|c|c|c|}
\hline Level & I & II & III & IV \\
\hline $\begin{array}{c}\text { Speed of roads } \\
(\mathrm{km} / \mathrm{h})\end{array}$ & 9,5 & 20,5 & 25 & 50 \\
\hline Transport time (s) & $\mathrm{S} / 9,5$ & $\mathrm{~S} / 20,5$ & $\mathrm{~S} / 25$ & $\mathrm{~S} / 50$ \\
\hline $\begin{array}{c}\text { Delays of lead } \\
\text { time (s) }\end{array}$ & $\mathrm{S} / 9,5-\mathrm{L}$ & $\mathrm{S} / 20,5-\mathrm{L}$ & $\mathrm{S} / 25-\mathrm{L}$ & $\mathrm{S} / 50-\mathrm{L}$ \\
\hline
\end{tabular}
\end{tabular}

\subsection{Switched model of the supply chain 3.2.1 Problem descriptions and assumptions}

Fig. 1 shows the three-stage supply chain system composed of suppliers, manufacturers, and retailers. 


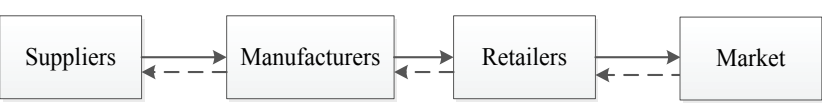

Figure 1 Three-stage supply chain system

The detailed assumptions in this study are as follows:

(1) When the inventory of manufacturers and retailers is insufficient, the inventory will be completely delivered to meet the orders, and the rest will have to wait for the next period.

(2) Manufacturers and retailers check the inventory at the end of each period.

(3) The inventory of suppliers can always meet the demand of manufacturers.

(4) The loss of in-transit inventory is 0 .
(5) The order delay period for all members is 1.

(6) The lead time from suppliers to manufacturers is $l$, whereas that from manufacturers to retailers is $n l$.

(7) The supply chain members forecast the demands using exponential smoothing method.

(8) Ten units of raw materials are transferred into a 1unit product.

(9) In normal conditions, the average speed of all members is $70 \mathrm{~km} / \mathrm{h}$.

The periodic activities of manufacturers and retailers are shown in Fig. 2.

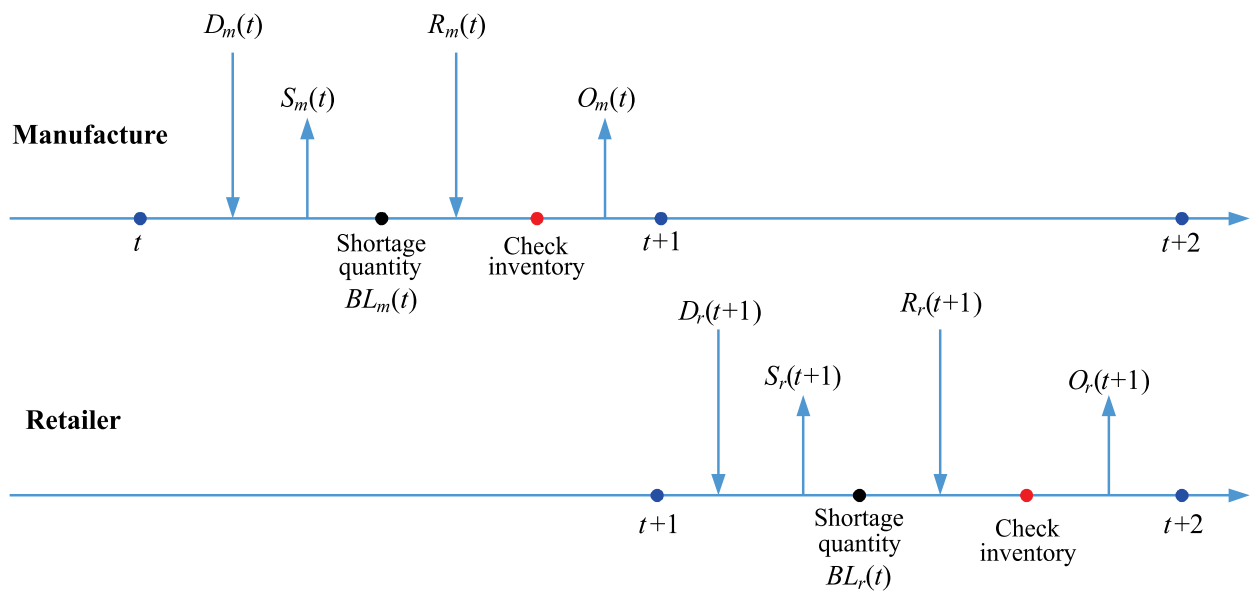

Figure 2 Activity diagram of a supply chain

Where: $s$ - supplier; $m$ - manufacturer; $r$ - retailer; $t$ period $(t=1,2,3, \ldots) ; O_{i}(t)$ - ordering quantity of member $i$ in period $t ; R_{i}(t)$ - receiving quantity of member $i$ in period $t ; S_{i}(t)$ - delivery quantity of member $i$ in period $t$; $I_{i}(t)$ - holding inventory of member $i$ in period $t$; WIP $(t)$ in-transit inventory of member $i$ in period $t ; F_{i}(t)-$ forecast demand of member $i$ in period $t ; B L_{i}(t)$ - shortage demand of member $i$ in period $t ; W I P_{i}^{0}(t)$ - expected intransit inventory of member $i ; I_{i}^{0}(t)$ - expected inventory of member $i$; $D(t)$ - market demand.

\subsubsection{Model formulation}

Exponential smoothing is used to forecast demands, as shown in Eq. (1).

$$
F_{i}(t)=\theta F_{i}(t-1)+(1-\theta) D_{i}(t), i \in\{m, r\}
$$

where $\theta$ is the smoothing constant, and $D_{s}(t)=O_{m}(t-1)$, $D_{r}(t)=D(t)$. (2):

The inventory in the warehouse is expressed by Eq.

$$
I_{i}(t)=I_{i}(t-1)+R_{i}(t)-S_{i}(t), i \in\{m, r\}
$$

The shortage quantity is expressed by Eq. (3):

$$
B L_{i}(t)=B L_{i}(t-1)+S_{i}(t)-D_{i}(t), i \in\{m, r\}
$$

The delivery quantity is shown in Eq. (4):

$S_{i}(t)=B L_{i}(t-1)+O_{j}(t-1), i \in\{s, m, r\}, j \in(m, r)$

Given that the supplier can meet the needs of the manufacturer,

$S_{s}(t)=O_{m}(t-1)$

The delivery quantities of the manufacturer and retailer are shown in Eqs. (6) and (7).

$$
\begin{aligned}
& S_{m}(t)= \begin{cases}O_{r}(t-1)-B L_{m}(t-1) & I_{m}(t-1) \geq O_{r}(t-1)-B L_{m}(t-1) \\
I_{m}(t-1) & 0 \leq I_{m}(t-1) \leq O_{r}(t-1)-B L_{m}(t-1) \\
0 & I_{m}(t-1) \leq 0\end{cases} \\
& S_{r}(t)= \begin{cases}D(t)-B L_{r}(t-1) & I_{r}(t-1) \geq D(t)-B L_{r}(t-1) \\
I_{r}(t-1) & 0 \leq I_{r}(t) \leq D(t)-B L_{r}(t-1) \\
0 & I_{r}(t) \leq 0\end{cases}
\end{aligned}
$$

The inventory in transit is shown in Eq. (8).

$W I P_{i}(t)=W I P_{i}(t-1)+S_{j}(t)-R_{i}(t), i \in\{m, r\}, j \in(s, m)(8)$

The APIOBPCS strategy is adopted, where $O_{i}(t)$ is expressed as Eq. (9).

$O_{i}(t)=F_{i}(t)+\alpha\left(I_{i}^{0}-I_{i}(t)\right)+\beta\left(W I P_{i}^{0}-W I P_{i}(t)\right), i \in\{m, r\}(9)$ 
where: $\alpha$ is the adjustment coefficient of the inventory in the warehouse, $\beta$ is the adjustment coefficient of the inventory in transit. $I_{i}^{0}$ is the expected inventory level in the warehouse. $W I P_{i}^{0}$ is the expected inventory level in transit.

Given that the inventory in transit sufficiently meets all the demand in lead time, the following Eq. (10) is obtained:

$W I P_{i}^{0}=L * F_{i}(t)$

The variables of the system state are defined as $I_{i}(t)$, $F_{i}(t), \quad W I P_{i}(t), \quad B L_{i}(\mathrm{t})$ as the space state model is established. $I_{i}^{0}$ is the reference input, $D(t)$ is the external interference, and $I_{i}(t)+B L_{i}(\mathrm{t})$ is the system output. The state space equation is shown in Eq. (11).

$$
\left\{\begin{array}{l}
I_{m}(t)=I_{m}(t-1)+O_{m}(t-l-2)-S_{m}(t) \\
F_{m}(t)=\theta F_{m}(t-1)+(1-\theta) O_{r}(t-1) \\
W I P_{m}(t)=W I P_{m}(t-1)+O_{m}(t-1)-O_{m}(t-l-2) \\
B L_{m}(t)=B L_{m}(t-1)+S_{m}(t)-O_{r}(t-1) \\
I_{r}(t)=I_{r}(t-1)+S_{m}(t-n l-1)-D(t) \\
F_{r}(t)=\theta F_{r}(t-1)+(1-\theta) D(t) \\
W I P_{r}(t)=W I P_{r}(t-1)+S_{m}(t)-S_{m}(t-n l-1) \\
B L_{r}(t)=B L_{r}(t-1)+S_{r}(t)-D(t)
\end{array}\right.
$$

where $S_{m}(t)$ and $S_{m}(t-n l-1)$ are variables. Moreover, $l$ has four possibilities when the system encounters four levels of disruptions. Based on this, the switch rules are extracted.

\subsubsection{Switch rules}

First, we define

$$
X(t)=\left[I_{r}(t), F_{r}(t), W I P_{r}(t), I_{m}(t), B L_{m}(t), F_{m}(t), W I P_{m}(t)\right]^{\mathrm{T}}
$$
and $r(t)=\left[I_{r}^{0}, I_{m}^{0}, D(t)\right]^{\mathrm{T}}$.

\section{(1) Manufacturer's inventory is sufficient}

We substitute $\quad S_{m}(t)=O_{r}(t-1)-B L_{m}(t-1)$, $S_{m}(t-n l-1)=O_{r}(t-n l-2)-B L_{m}(t-n l-2)$ into Eq. (11), and it can be expressed in Eq. (12).

$$
X(t)=A_{1} X(t-1)+B_{1} X(t-l-2)+C_{1} X(t-n l-2)+D_{1} r(t)(12)
$$

where

$$
A_{1}=\left[\begin{array}{ccccccc}
1 & 0 & 0 & 0 & 0 & 0 & 0 \\
0 & \theta & 0 & 0 & 0 & 0 & 0 \\
-\alpha & -(1+n \beta l) & 1-\beta & 0 & -1 & 0 & 0 \\
\alpha & -(1+n \beta l) & \beta & 1 & 1 & 0 & 0 \\
0 & 0 & 0 & 0 & 0 & 0 & 0 \\
-\alpha(\theta-1) & (1-\theta)(1+n \beta l) & (\theta-1) \beta & 0 & 0 & \theta & 0 \\
0 & 0 & 0 & -\alpha & 0 & 1+\beta l & 1-\beta
\end{array}\right]
$$

$B_{1}=\left[\begin{array}{ccccccc}0 & 0 & 0 & 0 & 0 & 0 & 0 \\ 0 & 0 & 0 & 0 & 0 & 0 & 0 \\ 0 & 0 & 0 & 0 & 0 & 0 & 0 \\ 0 & 0 & 0 & -10 \alpha & 0 & 10(1+\beta l) & -10 \beta \\ 0 & 0 & 0 & 0 & 0 & 0 & 0 \\ 0 & 0 & 0 & 0 & 0 & 0 & 0 \\ 0 & 0 & 0 & \alpha & 0 & -(1+\beta l) & \beta\end{array}\right]$

$C_{1}=\left[\begin{array}{ccccccc}-\alpha & 1+n \beta l & -\beta & 0 & -1 & 0 & 0 \\ 0 & 0 & 0 & 0 & 0 & 0 & 0 \\ \alpha & -(1+n \beta l) & \beta & 0 & 1 & 0 & 0 \\ 0 & 0 & 0 & 0 & 0 & 0 & 0 \\ 0 & 0 & 0 & 0 & 0 & 0 & 0 \\ 0 & 0 & 0 & 0 & 0 & 0 & 0 \\ 0 & 0 & 0 & \alpha & 0 & 0 & 0\end{array}\right]$

$D_{1}=\left[\begin{array}{ccc}\alpha & 0 & -1 \\ 0 & 0 & 0 \\ 0 & 0 & 0 \\ -\alpha & 10 \alpha & 0 \\ 0 & 0 & 0 \\ (1-\theta) \alpha & 0 & 0 \\ 0 & 0 & 0\end{array}\right]$

New switch rules will be established when the system encounters one of these four levels.

1) Highly serious

As shown in Tab. 2, when a highly serious disruption occurs, $l^{*}=S / 9,5$, where $S$ is the distance between the manufacturer and supplier. $n$ is the distance coefficient. $n S$ is the distance between the manufacturer and retailer. Under normal conditions, $l=S / 70$, so $l^{*}=7,4 l$. The space state equation is shown in Eq. (13).

$X(t)=A_{11} X(t-1)+B_{11} X(t-l-2)+C_{11} X(t-n l-2)+D_{11} r(t)(13)$

where

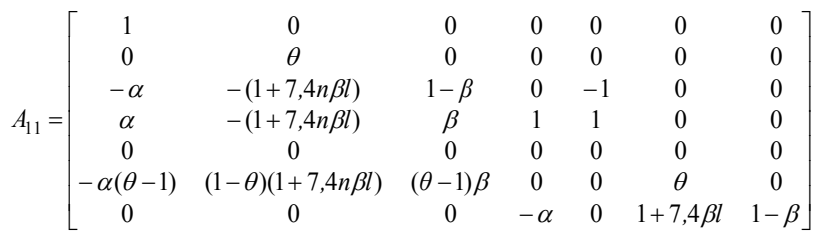

$B_{11}=\left[\begin{array}{ccccccc}0 & 0 & 0 & 0 & 0 & 0 & 0 \\ 0 & 0 & 0 & 0 & 0 & 0 & 0 \\ 0 & 0 & 0 & 0 & 0 & 0 & 0 \\ 0 & 0 & 0 & -0,1 \alpha & 0 & 0,1(1+7,4 \beta l) & -0,1 \beta \\ 0 & 0 & 0 & 0 & 0 & 0 & 0 \\ 0 & 0 & 0 & 0 & 0 & 0 & 0 \\ 0 & 0 & 0 & \alpha & 0 & -(1+7,4 \beta l) & \beta\end{array}\right]$

$C_{11}=\left[\begin{array}{ccccccc}-\alpha & 1+7,4 n \beta l & -\beta & 0 & -1 & 0 & 0 \\ 0 & 0 & 0 & 0 & 0 & 0 & 0 \\ -\alpha & -(1+7,4 n \beta l) & \beta & 0 & 1 & 0 & 0 \\ 0 & 0 & 0 & 0 & 0 & 0 & 0 \\ 0 & 0 & 0 & 0 & 0 & 0 & 0 \\ -\alpha(\theta-1) & 0 & 0 & 0 & 0 & \theta & 0 \\ 0 & 0 & 0 & 0 & 0 & 0 & 0\end{array}\right]$




$$
D_{11}=\left[\begin{array}{ccc}
\alpha & 0 & -1 \\
0 & 0 & 0 \\
0 & 0 & 0 \\
-\alpha & 0,1 \alpha & 0 \\
0 & 0 & 0 \\
(1-\theta) \alpha & 0 & 0 \\
0 & 0 & 0
\end{array}\right]
$$

\section{2) Serious}

Similarly, we obtain $l^{*}=3,4 l$. The space state equation is shown as Eq. (14).

$X(t)=A_{12} X(t-1)+B_{12} X(t-l-2)+C_{12} X(t-n l-2)+D_{12} r(t)$

3) Relatively serious

Likewise, $l^{*}=2,8 l$, and the space state equation is expressed as Eq. (15).

$X(t)=A_{13} X(t-1)+B_{13} X(t-l-2)+C_{13} X(t-n l-2)+D_{13} r(t)(15$

In this way, $A_{13}, B_{13}, C_{13}, D_{13}$ is omitted.

4) General

Similarly, $l^{*}=1,8 l$, and the space state equation is presented as Eq. (16).

$X(t)=A_{14} X(t-1)+B_{14} X(t-l-2)+C_{14} X(t-n l-2)+D_{14} r(t)$

In this manner, $A_{14}, B_{14}, C_{14}, D_{14}$ is omitted.

\section{(2) Manufacturer's inventory is insufficient}

Lead time will also change when the system encounters four levels of disruptions. The detailed equations of four disruption levels will not be described due to the similar formula derivation process. In this study, the switched model is shown in Eq. (17).

$X(t)=A_{2} X(t-1)+B_{2} X(t-l-2)+C_{2} X(t-n l-2)+D_{2} r(t)($

\section{(3) Manufacturer's inventory is zero}

Similarly, a model of switched system is established, as shown in Eq. (18).

$X(t)=A_{3} X(t-1)+B_{3} X(t-l-2)+C_{3} X(t-n l-2)+D_{3} r(t)(18)$

In summary, the model of the switched system is established based on the inventory dynamics and disruptions of different levels, as shown in Eq. (19).

$$
\begin{aligned}
X(t)= & A_{\sigma_{i j}} X(t-1)+B_{\sigma_{i j}} X(t-l-2)+ \\
& +C_{\sigma_{i j}} X(t-n l-2)+D_{\sigma_{i j}} r(t) \\
& i \in\{1,2,3\}, j \in\{1,2,3,4\}
\end{aligned}
$$

The switch rules are as follows:

$$
\begin{aligned}
& \sigma_{1 j}=\operatorname{sign}\left(I_{\mathrm{m}}(t-1)-O_{\mathrm{r}}(t-1)+B L_{\mathrm{m}}(t-1)\right) \\
& \sigma_{2 j}=\operatorname{sign}\left(I_{\mathrm{m}}(t-1)\right) \\
& \sigma_{3 j}=\operatorname{sign}\left(-I_{\mathrm{m}}(t-1)\right)
\end{aligned}
$$

$$
\begin{aligned}
& \sigma_{i 1}=\operatorname{sign}\left(l^{*}-7,4 l\right) \\
& \sigma_{i 2}=\operatorname{sign}\left(l^{*}-3,4 l\right) \\
& \sigma_{i 3}=\operatorname{sign}\left(l^{*}-2,8 l\right) \\
& \sigma_{i 4}=\operatorname{sign}\left(l^{*}-1,8 l\right)
\end{aligned}
$$

The switch rules are summarized in Tab. 3 .

Table 3 Switch rules

\begin{tabular}{|l|c|}
\hline$\sigma_{11}$ & $\operatorname{sign}\left(I_{\mathrm{m}}(t-1)-O_{\mathrm{r}}(t-1)+B L_{\mathrm{m}}(t-1)\right) \& \operatorname{sign}\left(l^{*}-7,4 l\right)$ \\
\hline$\sigma_{12}$ & $\operatorname{sign}\left(I_{\mathrm{m}}(t-1)-O_{\mathrm{r}}(t-1)+B L_{\mathrm{m}}(t-1)\right) \& \operatorname{sign}\left(l^{*}-3,4 l\right)$ \\
\hline$\sigma_{13}$ & $\operatorname{sign}\left(I_{\mathrm{m}}(t-1)-O_{\mathrm{r}}(t-1)+B L_{\mathrm{m}}(t-1)\right) \& \operatorname{sign}\left(l^{*}-2,8 l\right)$ \\
\hline$\sigma_{14}$ & $\operatorname{sign}\left(I_{\mathrm{m}}(t-1)-O_{\mathrm{r}}(t-1)+B L_{\mathrm{m}}(t-1)\right) \& \operatorname{sign}\left(l^{*}-1,8 l\right)$ \\
\hline$\sigma_{21}$ & $\operatorname{sign}\left(I_{\mathrm{m}}(t-1)\right) \& \operatorname{sign}\left(l^{*}-7,4 l\right)$ \\
\hline$\sigma_{22}$ & $\operatorname{sign}\left(I_{\mathrm{m}}(t-1)\right) \& \operatorname{sign}\left(l^{*}-3,4 l\right)$ \\
\hline$\sigma_{23}$ & $\operatorname{sign}\left(I_{\mathrm{m}}(t-1)\right) \& \operatorname{sign}\left(l^{*}-1,8 l\right)$ \\
\hline$\sigma_{24}$ & $\operatorname{sign}\left(I_{\mathrm{m}}(t-1)\right) \& \operatorname{sign}\left(l^{*}-2,8 l\right)$ \\
\hline$\sigma_{31}$ & $\operatorname{sign}\left(-I_{\mathrm{m}}(t-1)\right) \& \operatorname{sign}\left(l^{*}-7,4 l\right)$ \\
\hline$\sigma_{32}$ & $\operatorname{sign}\left(-I_{\mathrm{m}}(t-1)\right) \& \operatorname{sign}\left(l^{*}-3,4 l\right)$ \\
\hline$\sigma_{33}$ & $\operatorname{sign}\left(-I_{\mathrm{m}}(t-1)\right) \& \operatorname{sign}\left(l^{*}-2,8 l\right)$ \\
\hline$\sigma_{34}$ & $\operatorname{sign}\left(-I_{\mathrm{m}}(t-1)\right) \& \operatorname{sign}\left(l^{*}-1,8 l\right)$ \\
\hline
\end{tabular}

\section{Result analysis and discussion}

Judging the stability of the triple-delay discrete state space model established in this study is difficult with traditional methods. Thus, we utilize Matlab simulation to study the effect of disruptions on the supply chain.

\subsection{Sensitivity analysis of $\alpha, \beta$ under normal inventory fluctuation}

4.1.1 When $n$ and $\theta$ are constants $(n=1, \theta=0,001)$

When $l=1$, the threshold of stability is $\alpha \leq 0,29, \beta \leq$ 0,003 , and when $l=2$ and $l=3$, the threshold is $\alpha \leq 0,20$, $\beta \leq 0,002$ and $\alpha \leq 0,16, \beta \leq 0,0009$, respectively. The simulation figures when $l=1, \alpha \leq 0,29, \beta \leq 0,003, l=2, \alpha$ $\leq 0,20, \beta \leq 0,002$, and $l=3, \alpha \leq 0,16, \beta \leq 0,0009$ are shown in Figs. 3, 4 and 5, respectively.

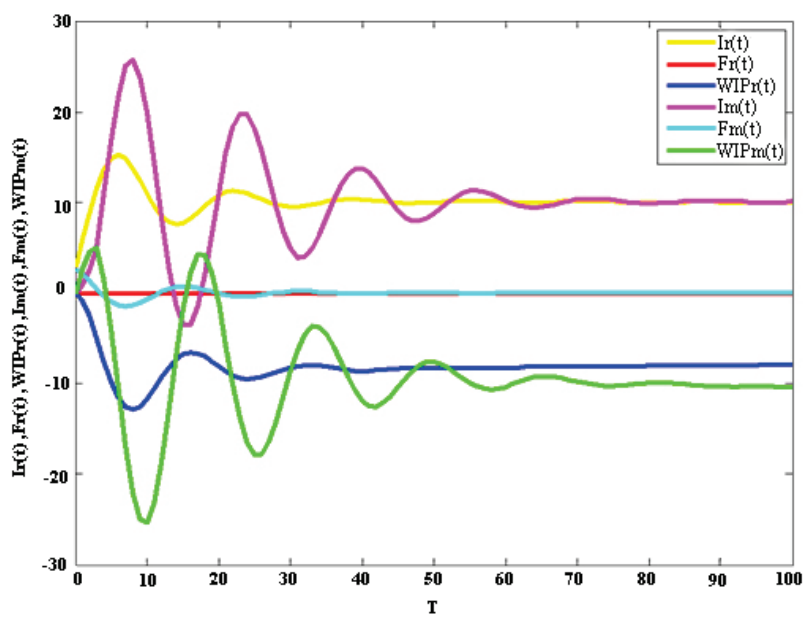

Figure 3 Simulation result when $1=1, \alpha \leq 0,29, \beta \leq 0,003$ 
The stability threshold of $\alpha, \beta$ decreases as increases. Moreover, $\alpha$ affects the system stability more than $\beta$, but $\beta$ is more sensitive.

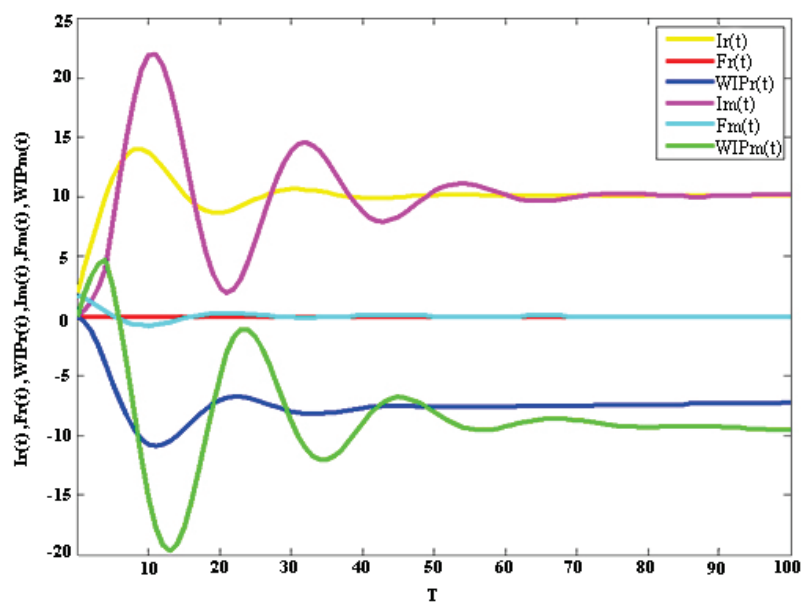

Figure 4 Simulation result when $l=2, \alpha \leq 0,20, \beta \leq 0,002$

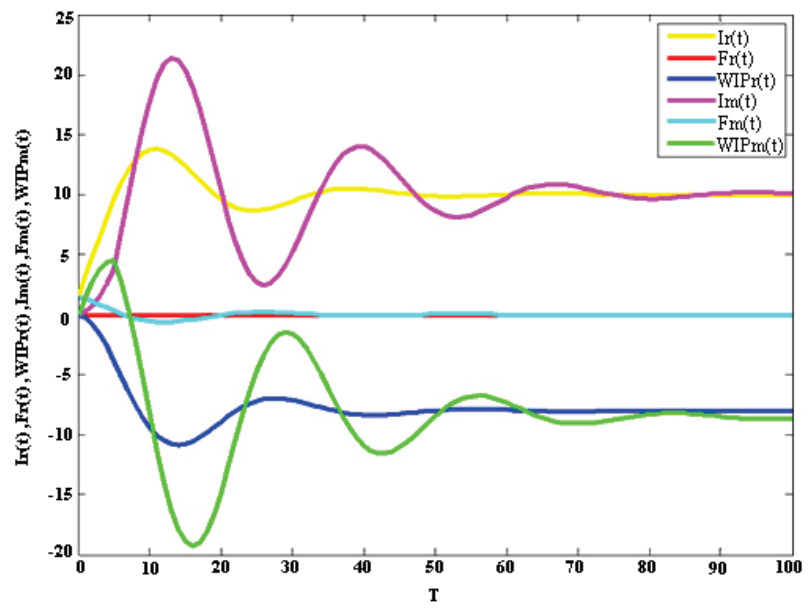

Figure 5 Simulation result when $l=3, \alpha \leq 0,16, \beta \leq 0,0009$

\subsubsection{When $n$ and $\theta$ are constants $(n=2, \theta=0,001)$}

When $n=1$, the threshold of stability is $\alpha \leq 0,20, \beta \leq$ 0,002 , and when $n=2$ and $n=3$, the threshold is $\alpha \leq$ $0,14, \beta \leq 0,001$ and $\alpha \leq 0,09, \beta \leq 0,0009$, respectively. The simulation figures when $n=1, \alpha \leq 0,20, \beta \leq 0,002, n$ $=2, \alpha \leq 0,14, \beta \leq 0,001$ and $n=3, \alpha \leq 0,09, \beta \leq 0,0009$ are in Figs. 6, 7 and 8, respectively.

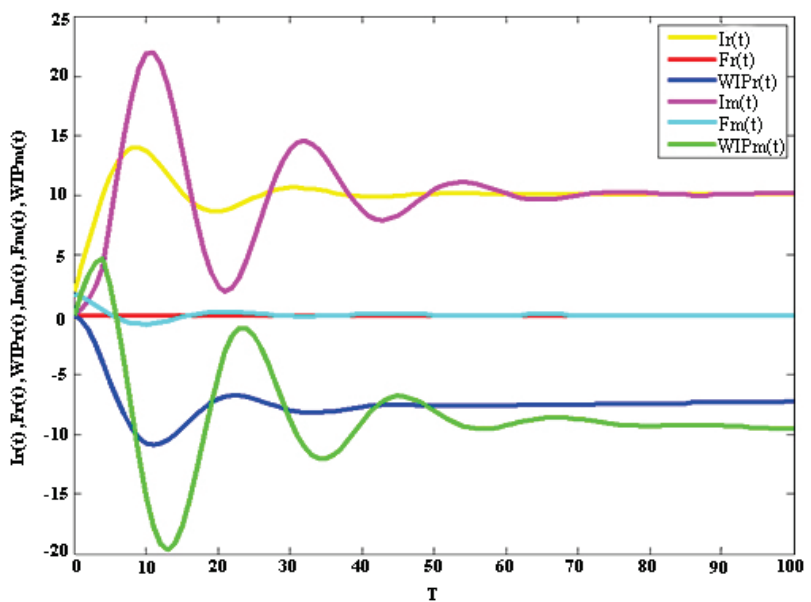

Figure 6 Simulation result when $n=1, \alpha \leq 0,20, \beta \leq 0,002$

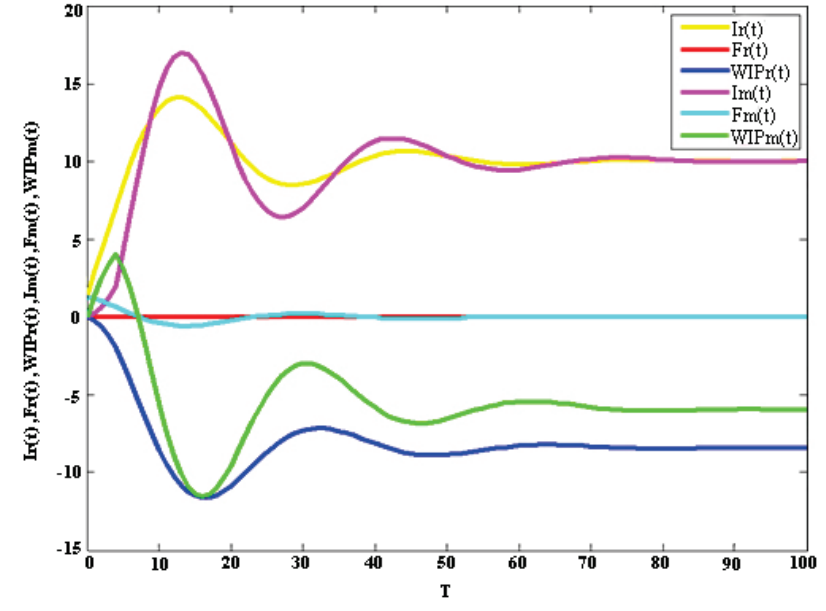

Figure 7 Simulation result when $n=2, \alpha \leq 0,14, \beta \leq 0,001$

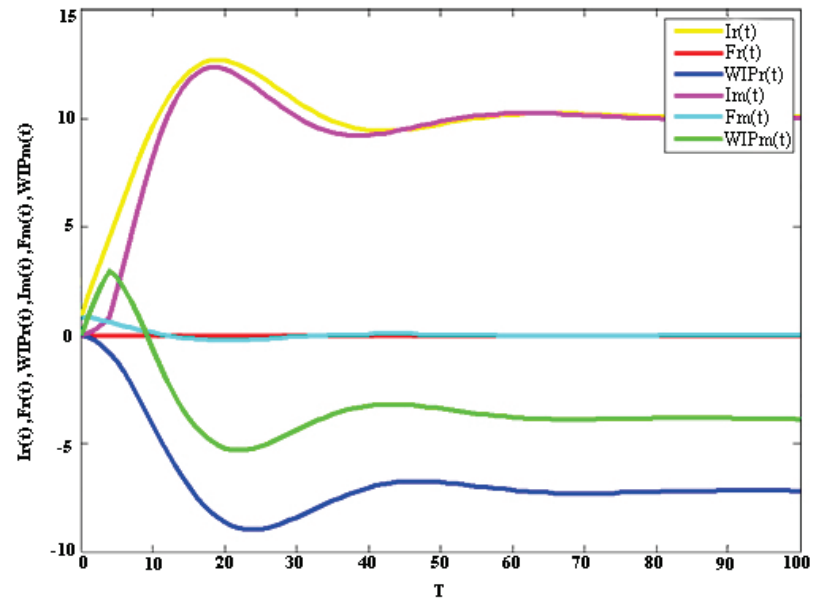

Figure 8 Simulation result when $n=3, \alpha \leq 0,09, \beta \leq 0,0009$

We can find that the threshold of $\alpha, \beta$ decreases as $n$ increases.

\subsection{Simulation of the stability under different disruption levels}

We assume $\alpha=0,3, \beta=0,001, \theta=0,1, n=1, l=3$, and the system will suffer a disruption at the beginning of the $50^{\text {th }}$ period.

\subsubsection{Highly serious}

In Fig. 9, the manufacturers' inventories in transit and stock in the warehouses both fluctuate dramatically; their maximum amplitudes are 43 and 58, and the gaps between peaks and valleys are 65,4 and 70,2, respectively. The system becomes more unstable and cannot recover to stability within the period $(T=100)$.

\subsubsection{Serious}

Similarly, in Fig. 10, the manufacturers' inventories fluctuate considerably, and the system is unstable within the period $(T=100)$. Compared with Fig. 9, the fluctuation reduces, which indicates that the interference weakens when disruption level decreases. 


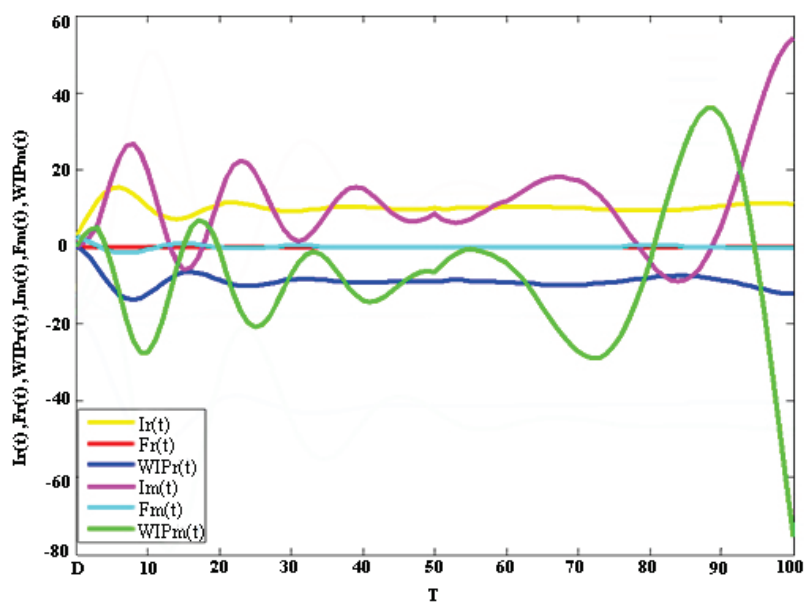

Figure 9 Supply chain performances under highly serious disruptions

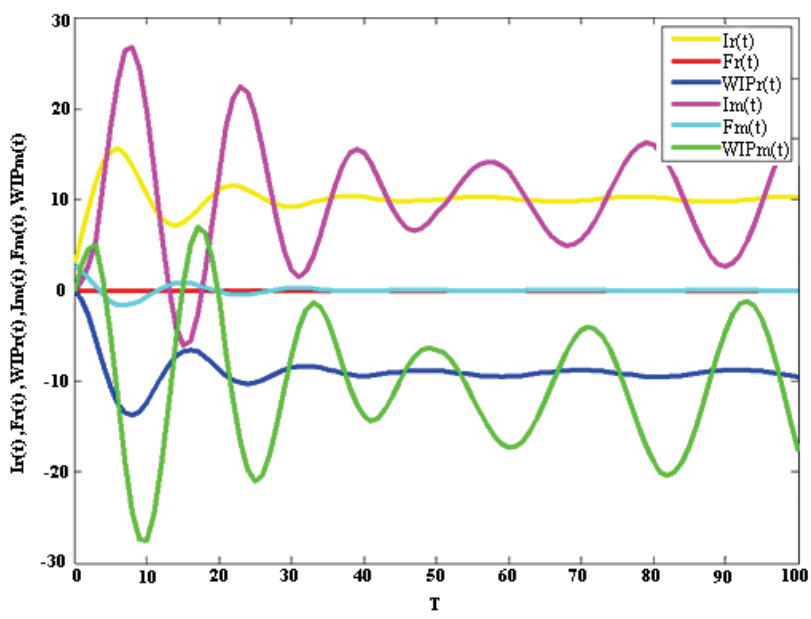

Figure 10 Supply chain performances under serious disruptions

\subsubsection{Relatively serious}

In Fig. 11, although the manufacturers' inventories fluctuate, the system tends to recover within the period ( $T$ $=100)$. Research shows that under this level of disruptions, the supply chain can respond efficiently and recover stability by adjusting its operation ultimately.

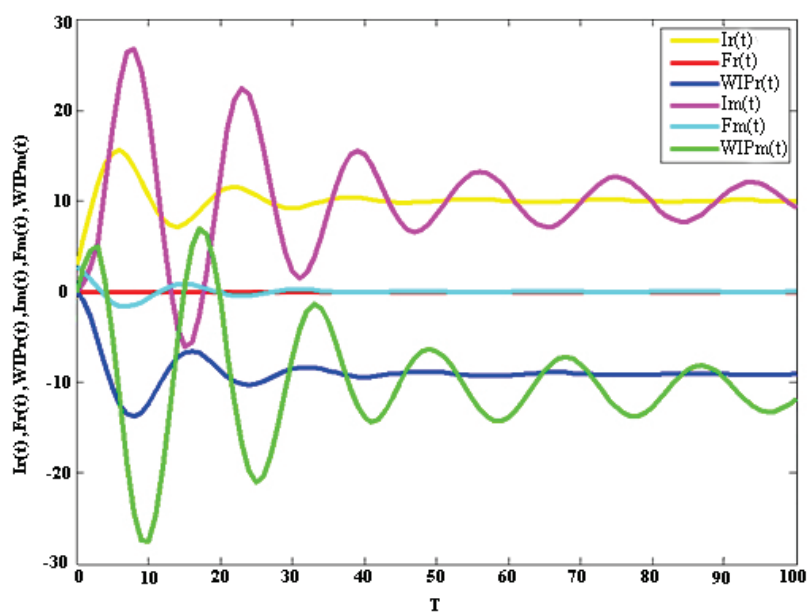

Figure 11 Supply chain performances under relatively serious disruptions

\subsubsection{General}

In Fig. 12, the manufacturers' inventories stabilize with time. Finally, the system recovers stability in the 80th period, showing that the supply chain can remove the inference of disruptions within a short period.

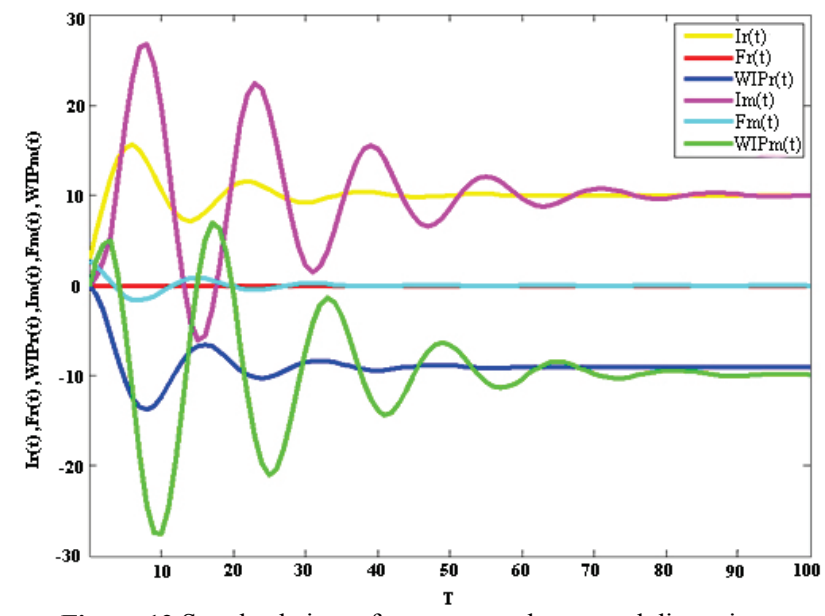

Figure 12 Supply chain performances under general disruptions

In conclusion, disruptions weakly affect the retailers' inventory but significantly affect the manufacturers' inventory, including inventories in transit and stock in the warehouses. Meanwhile, different disruption levels influence the stability of the system in varying degrees. Particularly, highly serious and serious disruptions significantly make the system fluctuate within the research period. This fluctuation is characterized by large amplitudes, long recovery time, and apparent fluctuations in quantity. The relatively serious and general disruptions also certainly affect system stability, but the system can recover by itself in a short time.

\subsection{Simulation of the stability under disruptions of whole process}

The whole process of disruptions from the occurrence to ending is complex. In similar instances, the system will bifurcate when it suffers disruption signals at various intensities.

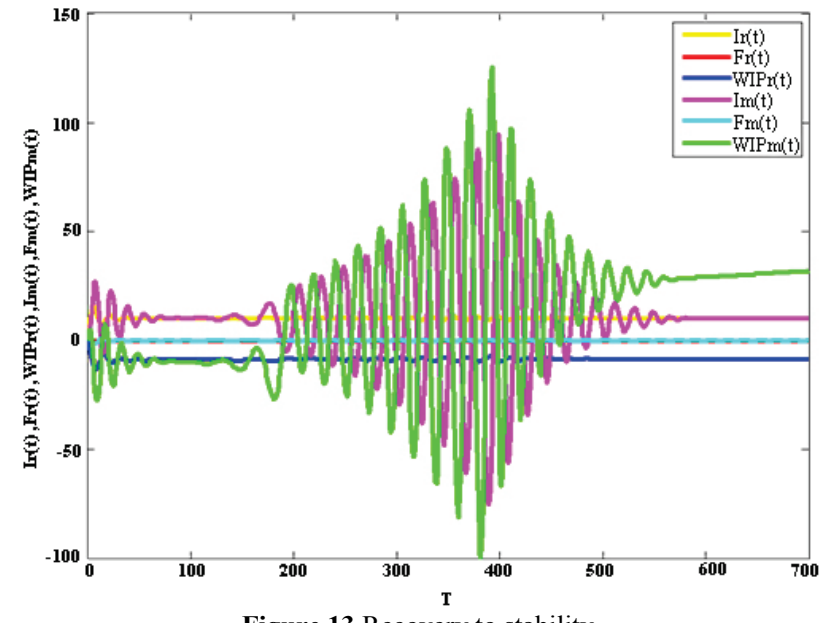

Figure 13 Recovery to stability 


\subsubsection{Recover to stability}

When an interference signal of low intensity is imposed on the supply chain system, the state evolution of the supply chain is illustrated in Fig. 13. The entire process includes incubating, bursting, spreading, and eventually recovering stability by itself.

After the system restores stability, the manufacturers' inventory increases by 38 units. Although the supply chain can stabilize itself, irreversible negative impact still occurs afterwards.

\subsubsection{Crash}

The system will crash when disruptions are too strong to tolerate. As shown in Fig. 14, the inventories fluctuate more obviously during the research period $(T=700)$, which means that it is impossible for the system to restabilize through self-regulation.

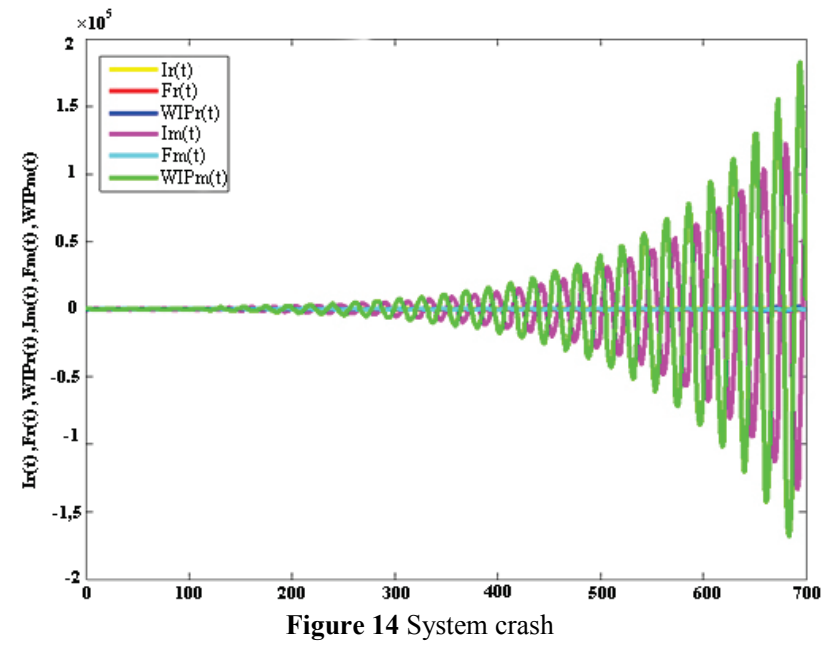

\section{Conclusion}

To address the lack of analysis on disruption characteristics in the stability research on supply chain under disruptions, switched theory was introduced to build the system model. The supply chain discrete linear switched model was established considering stock dynamics and lead time delays. Matlab/SIMULINK simulation was then utilized to identify the influence of various disruptions on the supply chain. The following conclusions are obtained:

(1) To establish the association between disruptions and supply chain stability, disruptions are classified into four categories according to the effect on transportation. The relationship between the disruption classification and lead-time delay is analyzed quantitatively, which considers the characteristics of disruptions and lays foundation for switched system modeling.

(2) In the sensitivity analysis, the stability threshold range of the inventory adjustment coefficient lessens as lead time and distance coefficient increases. In reality, increases in lead time and distance lengthen the reaction time of the system, thereby reducing the inventory adjustment for the system and order quantity.

(3) We find that different disruption levels influence system stability in varying degrees by conducting simulation. Moreover, the stability thresholds of the inventory in transit and the adjustment coefficient are sharply reduced, indicating that high disruption levels increase the vulnerability of the supply chain system and seriously impact system stability. During general disruptions, the system recovers stability by itself so the threshold range does not change obviously.

(4) By simulating disruptions throughout the life cycle, the supply chain is found to bifurcate under different levels of disruptions. In addition, the system stabilizes itself when the intensity of disruptions does not exceed the stable threshold, which is consistent with the practical performance and current analysis on the supply chain.

Moreover, the switched system model of supply chain is based on the inventory dynamics of members and level of disruptions, which discusses the relationship between the characteristics of disruptions and the evolution of the supply chain system and provides an idea for a new model of supply chain under disruptions. However, disruptions are complex and their characteristics change with the evolution stages, thus, comprehensive extraction of the dynamic characteristics should be considered in future studies. In comparison with the methods of Lyapunov, stability principle, and information entropy, simulation can only evaluate stability approximately from the trend of system evolution. Therefore, this study can be extended to clearly identify the border of stability and the threshold values of the switched model.

\section{Acknowledgements}

This study was supported by the National Natural Science Foundation of China (61503043), the China Postdoctoral Science Foundation (2014M552401), the Shaanxi Natural Science Foundation (2017JM7016, 2015JQ7272, and 2015JQ6214), and the China Fundamental Research Funds for the Central Universities (310822172204).

\section{References}

[1] Andres, M. V.; Cavada, M. O.; Arrien, O. U. Risk analysis for an industrial company in the Spanish electrical market. // DYNA. 90, 3(2015), pp. 314-323.

[2] Liu, H. X.; Wang, H. W.; Wang, Z. G. Modeling the dynamics of a two-stage supply chain: a switch system theory approach. // Journal of Huazhong University of Science and Technology. 21, 3(2005), pp. 151-155.

[3] $\mathrm{Hu}, \mathrm{M}$. M. Modeling and simulation of supply chain switched system with restrictions of production capability and delay. // Statistics and Decision. 8(2012), pp. 42-45.

[4] Li, Q. K.; Li, M.; Jia, X. C. Switching control of closedloop supply chain systems with Markov jumping parameters. // Acta Automatica Sinica. 41, 12(2015), pp. 2081-2091.

[5] Garcia, C. A.; Ibeas, A.; Vilanova, R. A switched control strategy for inventory control of the supply chain. // Journal of Process Control. 23, 6(2013), pp. 868-880. https://doi.org/10.1016/j.jprocont.2013.04.005

[6] Lu, Y. J.; Tang, X. W.; Zhou, Z. F. Study on the chaotic of production decision in integrative supply chain system. // Journal of Management Engineering. 119, 14(2005), pp. 31-35. 
[7] Xiao, Y. M.; Wang, X. Y. Early-warning analysis on stability of supply chain based on entropy theory. // Journal of Industrial Engineering and Engineering Management. 22, 3(2008), pp. 57-63.

[8] Zhang, X. L.; Wang, Y. F. LMI-based research on stability of leagile supply chain with grey non-linear characteristics. // Industrial Engineering Journal. 17, 2(2014), pp. 64-69.

[9] Hu, H.; Hu, D. W.; Chen, D. Study on entity correlation stability in supply chain coordination. // Industrial Engineering Journal. 14, 5(2011), pp. 31-35,41.

[10] Durowoju, O. A.; Chan, H. K.; Wang, X. J. Entropy assessment of supply chain disruption. // Journal of Manufacturing Technology Management. 23, 8(2012), pp. 998-1014. https://doi.org/10.1108/17410381211276844

[11] Luo, J. Z.; Yang, W. Control of supply chain based on switched model of stock level. // Mathematical Problems in Engineering. 2014, 3(2014), pp. 1-8. https://doi.org/10.1155/2014/464256

[12] Wang, Y. E.; Sun, X. M.; Mazenc, F. Stability of switched nonlinear systems with delay and disturbance. // Automatica. 69(2016), pp. 78-86. https://doi.org/10.1016/j.automatica.2016.02.015

[13] Ogura, M.; Preciado, V. M. Stability of Markov regenerative switched linear systems. // Automatica, 69(2016), pp. 169-175. https://doi.org/10.1016/j.automatica.2016.02.022

[14] Wilson, M. C. The impact of transportation disruptions on supply chain performance. // Transportation Research Part E: Logistics and Transportation Review. 43, 4(2007), pp. 295-320. https://doi.org/10.1016/j.tre.2005.09.008

[15] Oke, A.; Gopalakrishnan, M. Managing disruptions in supply chains: a case study of a retail supply chain. // International Journal of Production Economics. 118, 1(2009), pp. 168-174. https://doi.org/10.1016/j.jpe.2008.08.045

[16] Heckmann, I.; Comes, T.; Nickel, S. A critical review on supply chain risk-definition, measure and modeling. // Omega. 52(2015), pp. 119-132. https://doi.org/10.1016/j.omega.2014.10.004

[17]Jabbarzadeh, A.; Fahimnia, B.; Seuring, S. Dynamic supply chain network design for the supply of blood in disasters: a robust model with real world application. // Transportation Research Part E: Logistics and Transportation Review. 70, 1(2014), pp. 225-244. https://doi.org/10.1016/j.tre.2014.06.003

[18] Esmaeilikia, M.; Fahimnia, B.; Sarkis, J.; Govindan, K.; Kumar, A.; Mo, J. A tactical supply chain planning model with multiple flexibility options: an empirical evaluation. // Annals of Operations Research. 244, 2(2014), pp. 429-454. https://doi.org/10.1007/s10479-013-1513-2

[19] Sun, Q.; Ji, J. H. Study on the evolution processes of supply chain disruption based on fast restoration. // Soft Science. 26, 11(2012), pp. 58-62.

[20] Qin, Y. H.; Cao, X. Y.; Ruan, P.; Song, Q. N. The coordination of supply chain in the case of asymmetric information on the manufacturing cost and under disruptions. // Journal of Huazhong Normal University (Natural Science). 47, 2(2013), pp. 259-264.

[21] Ji, J. H.; Bao, X.; Sun, Q. Study on the diffusion mechanism and loss assessment of supply chain disruptions. China Science Publishing House, Beijing, 2013.

[22] Jeihani, M.; James, P.; Anthony A. S.; Ardeshiri, A. Traffic recovery time estimation under different flow regimes in traffic simulation. // Journal of Traffic and Transportation Engineering (English Edition). 2, 5(2015), pp. 291-300. https://doi.org/10.1016/j.jte.2015.08.001

\section{Authors' addresses}

Hui Hu, Ph.D., Associate Professor (Corresponding author)

School of Automobile, Chang' an University, Middle Section of South 2nd Ring Road,

Xi'an, 710064, Shaanxi Province, P. R. China

E-mail: huhui@chd.edu.cn

\section{Lei Shi, Graduate student}

School of Transportation, Southeast University, Southeast University Road No. 2,

Nanjing, 211189, Jiangsu Province, P. R. China

E-mail: 502980882@qq.com

\section{Hai Ma, Graduate student}

School of Automobile, Chang'an University, Middle Section of South 2nd Ring Road,

Xi'an, 710064, Shaanxi Province, P. R. China

E-mail:mh123wy@163.com

\section{Bin Ran, Ph.D., Professor}

Department of Civil \& Environmental Engineering, University of Wisconsin-Madison,

1212 Engineering Hall, 1415 Engineering Drive Madison, WI 53706, USA

E-mail: bran@wisc.edu 